\title{
International Organizations, Care and Migration: The Case of Migrant Health Care Workers
}

\author{
Nicola Yeates and Jane Pillinger
}

\section{INTRODUCTION}

This chapter focuses on international health care worker migration to illustrate shifting constellations of architectures of ideas, actors and institutions in global social governance and policy. The phenomenon of health worker migration and how the international community should respond to it is one that has long preoccupied International Organizations (IOs) (Yeates and Pillinger 2019a, b). It is the earliest case of care as an overtly institutionalized field of global social policy, long predating IOs' initiatives on childcare, domestic care and care of migrants. It has been an active area of global social policymaking throughout the post-WWII period. Thus, a discernible global social policy field of health care worker migration was instituted from the outset of the United Nations (UN), developing and

\footnotetext{
N. Yeates $(\bowtie) \bullet J$. Pillinger

Department of Social Policy and Criminology, The Open University, Milton Keynes, UK

e-mail: n.yeates@open.ac.uk

(C) The Author(s) 2021

K. Martens et al. (eds.), International Organizations in Global

Social Governance, Global Dynamics of Social Policy, https://doi.org/10.1007/978-3-030-65439-9_4
} 
expanding over the ensuing decades. As the chapter shows, this global policy field is complex, contested and dynamic. It is populated by numerous IOs and other transnational actors promulgating myriad discourses, forging international agreements and entering into partnership—some are complementary, others are competing.

One chapter cannot do justice to the field's complexity and dynamics, and therefore it focuses on mapping key contours of this global social policy field in the form of IOs operating on the most extensive multilateral scale. The chapter's core emphasis is therefore on global organizational sources of public authority; private sources of authority within global governance are outside the scope of the chapter. The discussion draws on our on-going work on this topic-most recently in a co-authored research monograph (Yeates and Pillinger 2019a) where we examine the origins of IOs' involvement in shaping the field and demonstrate the substantial long-standing history of global governance and policy in this field. There we amply showed how the institutional architectures and discourses of contemporary global health workforce migration governance and policy are best understood as being produced through intersections of multiple policy fields (notably, health, migration, social protection, labor, trade, equality and human rights). The full implications of this are discussed further in Yeates and Pillinger (2019a), but it is worth highlighting at this point that expanding the analytical vista beyond intersections of global health policy and global migration policy opens our gaze onto a far broader institutional terrain, a much wider range of IOs and transnational policy actors active in this field, and far more complex global social policy dynamics than has hitherto been appreciated. This chapter does not rehearse these arguments, but picks up key ideas from them. It incorporates additional analysis prepared purposefully for this chapter.

The remainder of the chapter is organized around four principal sections. Section "Mapping the Population of International Organizations" identifies the principal IOs active in the global policy field since the foundation of the UN system, showing how they have changed over time. It relates this changing IO population to the expanding 'universe' of state and non-state policy actors active in this field and discerns principal characteristics of this population over the period examined. Section "Key Discourses Promulgated by IOs" considers the IOs' policy discourses in this field. Emphasizing the multiplicity of policy concepts, approaches and discourses circulating in this field, we discuss the extent to which they are attributable to any single IO and how they might relate to IOs' 
organizational ecology. Here, IOs' organizational mandate and governance are accorded significance because they structure which actors participate in IOs' policy-formation processes and how they do so. In other words, mandates and governance structures determine who has proposal (and veto) rights within global policy. Section "Inter-actor Relationships of Cooperation, Coordination and Contestation" picks up on the multifarious nature of global social policy discourse(s) in this field, to discuss how they are shaped by cooperation, contestation and competition among IOs. We emphasize that such relations are integral to this field, albeit with an apparent trend in increased inter-IO cooperation, particularly over the last decade. This does not signal an erosion of competing policy approaches, which continue to be manifested in the context of the trend toward interIO global policy partnerships; contestation remains a central feature of the global policy field. Section "Conclusion" draws the chapter to a conclusion, where we synthesize key points from the discussion and reflect on these in terms of scalar and relational approaches to global social governance and policy.

\section{Mapping the Population OF INTERNATIONAL ORgANIZATIONS}

\section{Historical Constellations of International Organizations}

The numerous IOs constitute a significant share of the total population of transnational policy actors active in the global policy field of health worker migration. This section discusses the expansion of IOs involved in this field. It signals the extent to which the field has been marked by policy contestation, competition and coordination-a theme which is taken up in more detail in Sections "Key Discourses Promulgated by IOs" and "Inter-actor Relationships of Cooperation, Coordination and Contestation".

To begin with, it is worth noting that the organizational features of this global policy field share many of the characteristics of migration governance more generally. While the World Trade Organization (WTO) oversees trade negotiations and the International Monetary Fund (IMF), along with the Financial Stability Board, manages capital mobility, there is no single IO regulating migration. The World Health Organization (WHO) approaches issues of migration from a health needs and a 'human resources for health' perspective, while the International Labour Organisation (ILO) focuses on labor and social protection issues affecting 
all categories of labor, migrant or otherwise. The United Nations Children's Fund (UNICEF) has an interest in health worker migration from the perspective of children's rights to health, although it does not participate in shaping this policy field. United Nations Educational, Scientific and Cultural Organization's (UNESCO) interest is from the perspective of education and training, and in international educational exchanges and mobility of highly educated labor. United Nations Conference on Trade and Development's (UNCTAD) interest is in the labor content (migratory and otherwise) of the international trade/development nexus. The World Bank (WB) has an interest in migration as a factor in wider economic development. Only the International Organization for Migration (IOM) has a sole focus on migration issues, but for most of its history it has sat outside the UN system. It has no regulatory or standard-setting role, and in keeping with its main emphasis on lower-skilled migration, displacement and returns it does not cover skilled health worker migration other than through more general diasporic approaches (Yeates and Pillinger 2018, 2019a, 15). Various other consultative global fora operate within and outside of the UN to promote multilateral dialogue, such as the High-Level Dialogue on Migration and Development, the Global Migration Group and the Global Forum on Migration and Development (GFMD), though they have no role in the development of multilateral policies or standards and their involvement in health worker migration and recruitment has not been evident. The International Platform on Health Worker Mobility, which is part of the ILO, Organisation for Economic Co-operation and Development (OECD), WHO Working for Health program (HEEG 2016) (Section "Inter-actor Relationships of Cooperation, Coordination and Contestation"), builds upon the High-Level Dialogue on International Health Worker Migration that took place in Dublin in 2017.

Table 4 .1 below provides an overarching summary of the period examined. It plots the active IO population over time, along with key policy concepts and principal landmark agreements in the global policy field.

Against a backdrop of the General Agreement on Tariffs and Trade (GATT) international trade regime underpinning the post-WWII globalizing liberal order, the dominant IOs in this global policy field are member organizations of the UN system. The global policy field on international health worker migration originated within the UN system from its earliest days. WHO first reported on the consequences of the global dynamics of international health worker migration in the 1950s in the context of its 


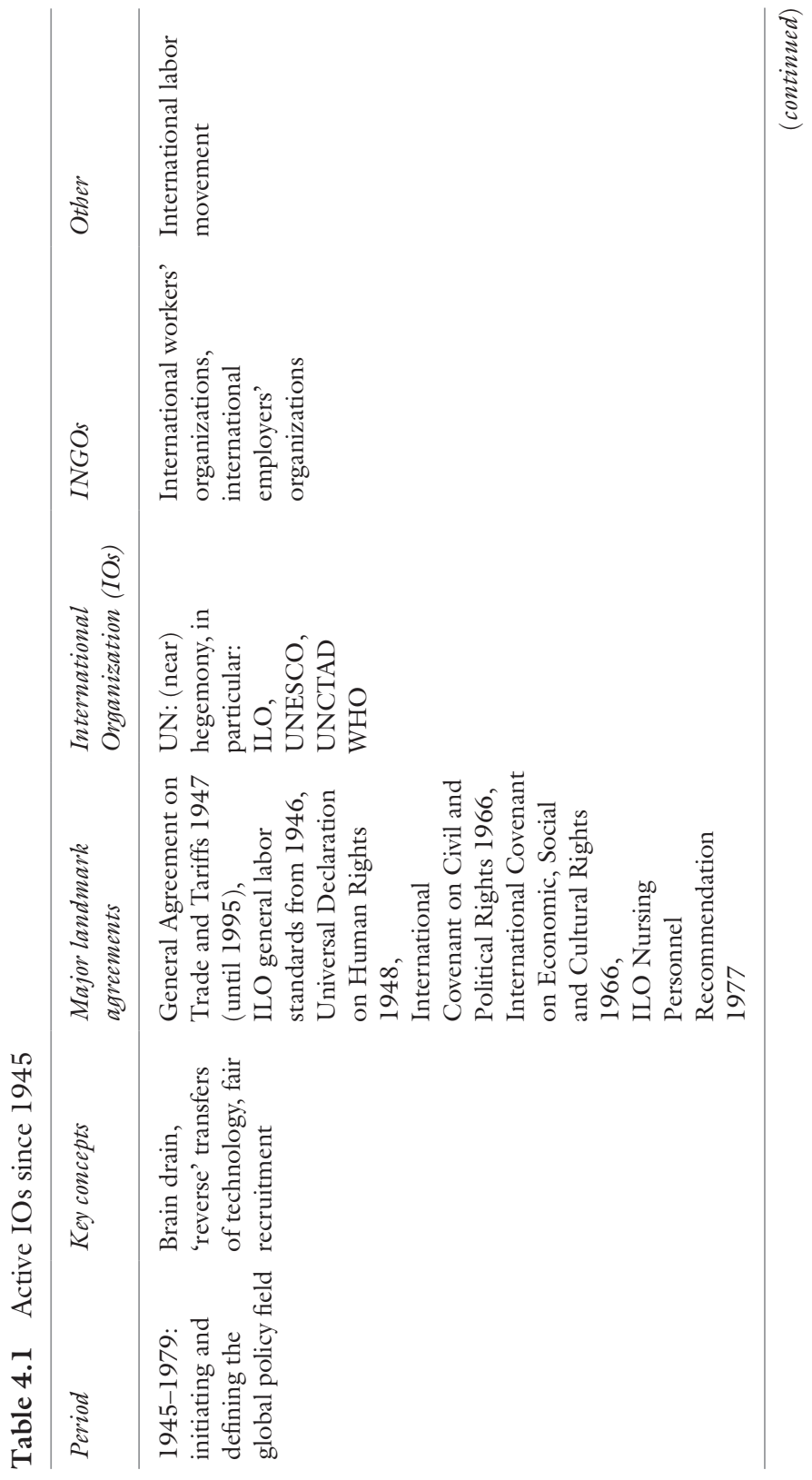




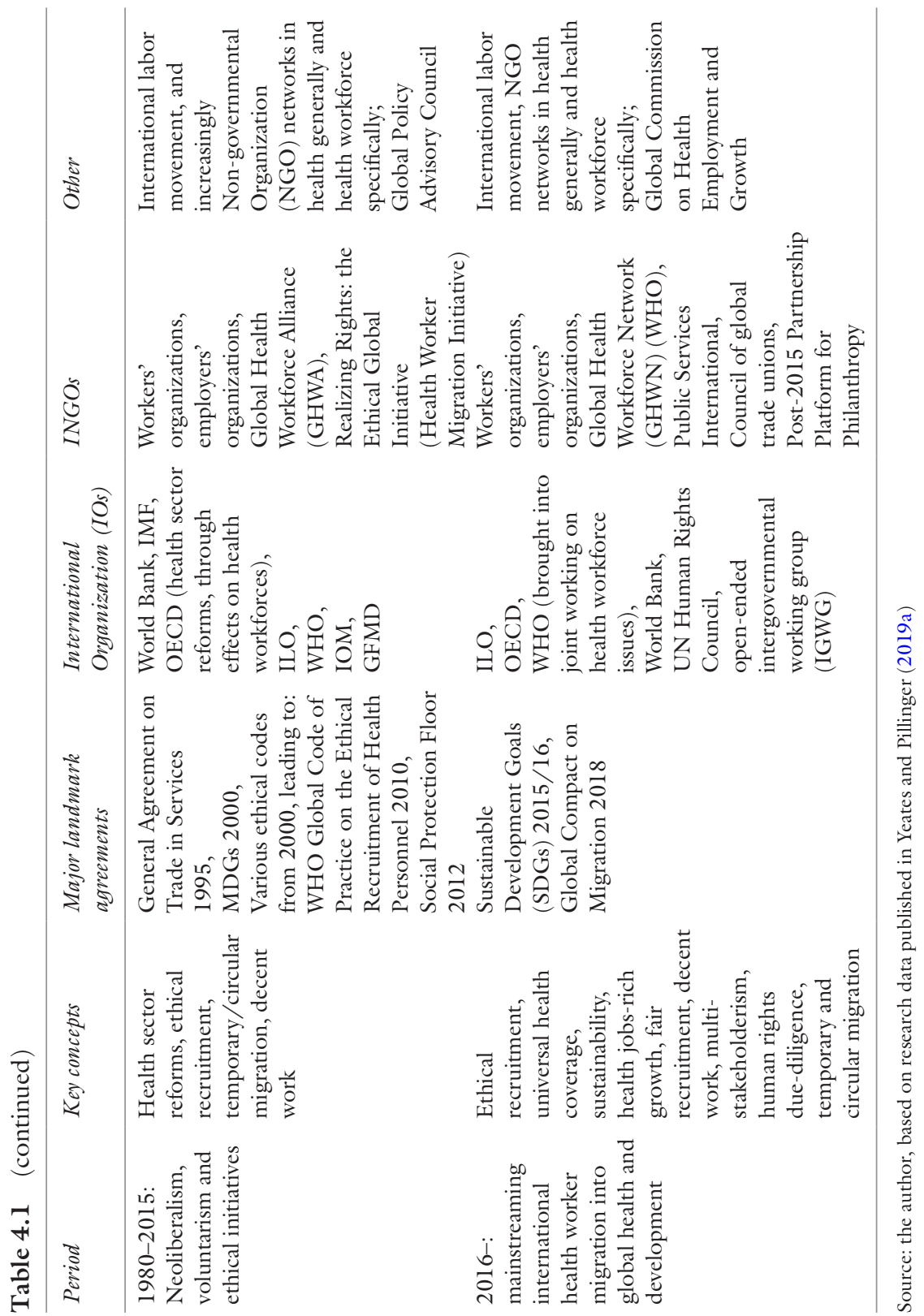


Fellowships scheme, but it did not initiate the global field as an arena of policy as political practice, nor was it a frontrunner in it for much of the field's early history. Indeed, for much of the post-war period, this space was dominated by UNESCO, UNCTAD and the ILO. WHO started to participate more actively in an already extant policy field at the end of the 1960s, within the terms of the debate set by these other UN agencies. These agencies were decisive in the early definition of the global policy field and had played a crucial role in identifying the global policy issues at stake since the early 1960s. UNESCO was the first UN (or any) global agency to explicitly identify international health worker migration as a global social policy issue, raising questions about the transfers of national (educational and training) resources involved in emigration. UNCTAD's focus on the 'brain drain' and 'reverse transfers of technology' framed health worker migration as a factor of economic and industrial development. Of note here are its attempts to negotiate an international agreement to regulate and help reverse highly skilled health care worker migration. The ILO's mandate meant its involvement was through the prism of international labor migration, instantiated through its tripartite elaboration of international labor standards. These standards were applicable to all workers and were not sector-specific, but nevertheless related to the recruitment and working conditions of migrant health workers in tangible ways. Organizations of employers and workers were the only non-state policy actors involved in shaping the field at the time, and this remained the case until the 2000s (Yeates and Pillinger 2019a).

The first global institutional landmark agreement was concluded in 1977 (ILO Nursing Personnel Recommendation). This was spurred by the ILO's activism in the mid-1970s on international labor migration and gender equality more generally, which unfolded in the context of the UN's New International Economic Order (NIEO) initiative and gave concrete expression to two international human rights covenants concluded in 1966. WHO had by this time initiated a major global study of medical and nurse migration, but although it had provided substantial ideational input it was unable to translate its conclusions and recommendations into a WHO Resolution or a general program of work or similar. This stalling did not seem to be due to a lack of demand by governments for international action. Indeed, this translational work was passed on to the ILO, which adopted a draft Recommendation in the space of a year. The rapid passage of a proposal into an agreement reflected the mounting 'anxiety' expressed by many source country governments throughout the 
1960s and 1970s of increasing emigration of their health workers and adverse impacts on their health systems. Correspondingly, it gave further impetus to the urgent need for internationally agreed-upon principles for the recruitment and employment of overseas health workers (Yeates and Pillinger 2019a).

The changed political and economic priorities of the late 1970s and 1980s marked a significant shift in the international political economy of global social policy, stalling momentum that could otherwise have built on the ILO Recommendation. IMF, WB and OECD policies on structural adjustment and health sector reforms strongly conditioned the working and living conditions of health workforces across many countries, which, combined with the liberalization of labor migration, contributed substantially to a growing global public health crisis in many countries. It was not that these IOs directly shaped global policy debate about health worker migration, but their activism in the wider realm of health and trade governance, notably through their promulgation of neoliberal and deregulatory social and economic reforms, impacted on the material conditions of health workforces that the UN (and its social agencies) had long been trying to address through labor, education and trade sectors. The effects of global neoliberalism on this global policy field were felt most keenly by the ILO, WHO, UNESCO and UNCTAD whose policy space to consolidate and extend prior agreements in the interests of migrant workers and developing countries' health services shrunk considerably. The growing emphasis on economic liberalization, market integration and voluntary self-regulation combined to stall the momentum gained by the UN agencies which had worked in formal and informal partnership with the labor movement and developing countries during the 1960s and 1970s. Such was the severity of that stalling that the 1980s and 1990s were, in effect, lost decades as far as progress in this policy field is concerned (Yeates and Pillinger 2019a, b).

The opening years of the twenty-first century marked somewhat of a turning point in this global policy field. In health, international development ministries, the labor movement and the increasing number of (International) Non-governmental Organizations ((I)NGOs) dedicated to global health workforce issues and international health worker migration were pressing forcefully for better regulation of international recruitment as a means of stemming the growing global public health crisis and wider development impacts that were disproportionately borne by those countries (especially in Africa and Asia) least able to bear the effects of 
health worker emigration. From the early 2000s, 'ethical recruitment' initiatives started to proliferate and, although these favored voluntary selfregulation, they influenced the discursive environment and empowered those (including WHO) calling for limits on the extent of recruitment of health workers from poor countries by rich ones (Yeates and Pillinger 2019a, b).

Elsewhere, growing activism to strengthen global migration governance and policy more generally forged new institutional spaces and processes outside of the UN system, notably in the GFMD and IOM ${ }^{1}$ which to some extent addressed health workforce issues and their intersections with migration. The GFMD proved to be a conduit for policy renewal in global health worker migration governance especially in relation to temporary and circular migration, a significant policy idea that also features prominently in World Bank and IOM discourses (Section "Key Discourses Promulgated by IOs"). During the 2000s, ethical recruitment initiatives not only proliferated but multilateralized, culminating in the second dedicated multilateral agreement in this global policy field-the Global Code of Practice on the Ethical Recruitment of Health Personnel (hereafter, Global Code) (WHO 2010). The alliance formed to advocate for and negotiate the Global Code reflected the expansion of the IO 'universe' since the 1970s. The ILO, WHO and IOM were especially active, alongside Ministers of Health, Labor and International Development from source and destination countries, and a highly active civil society initiative (Health Worker Migration Initiative (HWMI). ${ }^{2}$ The Global Code is a significant milestone in the history of the global policy field, though it is more permissive of continuing large-scale international migration and recruitment of health workers than the 1977 ILO Nursing Personnel Recommendation (Yeates and Pillinger 2019a, b).

The years after the 2010 Global Code were ones during which WHO consolidated its position as a principal IO in this global policy field. Its focus on the implementation of the Global Code paralleled efforts to mainstream issues of health worker recruitment and migration into global health and development policy, a feat achieved by its assertive stance on universal health coverage as a central global health policy objective (SDG 5 ). Yet WHO is by no means the sole IO in this global policy field. The

${ }^{1}$ IOM was incorporated into the UN in 2016.

${ }^{2}$ HWMI was a partnership between the NGO 'Realizing Rights: the Ethical Global Initiative' and the 'Global Health Workforce Alliance' (GHWA). 
leitmotifs of sustainability and international partnership facilitate a pluralistic and expansive universe of policy actors. The ILO continues to be highly active in this global policy field, focusing on labor rights, as does WHO, advocating a focus on health services within strengthened health systems. IOM's engagement with this field is sporadic and limited, but ultimately supportive of circular migration. The OECD continues to be a significant presence, bringing expertise in data production and analysis of OECD migration trends and support for continued international recruitment by OECD countries. The World Bank is also becoming a more central actor. It has been a major proponent of the argument that greater international economic integration within the framework of the WTO General Agreement on Trade in Services can facilitate greater mobility of health workers in ways that limit developing countries' losses (World Bank $2009,2012)$. Other interventions have revolved around health work force composition and 'task shifting', health worker-to-population ratios and health workforce labor markets. World Bank officials have argued that WHO staff-to-patient ratio norms are too high (Yeates and Pillinger 2013), challenging the international consensus that the ratios should be revised upwards.

The ILO, WHO and the World Bank-and prospectively, the WTOseem set to play a greater role in remaking the global policy field over the coming years. One driver of this is the Global Commission on Health Employment and Growth (HEEG 2016) which recommended an interIO global health workforce initiative led by the ILO, WHO and the World Bank, and involving the OECD. It remains to be seen how this inter-IO dynamic will unfold, what new policy actors will be brought into the arena, what discursive shifts it will produce and how these will be manifested in the dynamics and outcomes of global policy itself. However, there are already signs that WHO is taking on board the need for stronger lateral connections between health, trade and labor, even if inscribing these connections within a revised Global Code seems a step too far for it at the moment. It has extended consultative status to labor actors (notably, PSI), is adopting ILO's occupational classification for future use and seems to accept the need for greater emphasis on labor economics (associated most with the World Bank). It will be of interest to see what other policy actors are brought into WHO work in this evolving field and what role the WTO might play in the future. The WTO has self-consciously abstained from participating in this field on the grounds that GATS is about mobility and not migration. However, the WHO's discursive (and 
apparent institutional) shift from migration to mobility ${ }^{3}$ plus its prospectively greater attention to health labor economics may open opportunities for the WTO and the World Bank to become more prominent influences on the field.

The SDGs are a further driver creating spaces for additional IOs to join this policy field. Health worker migration and recruitment cuts across four SDGs (Health and Well-Being, Decent Work and Economic Growth, Reduced Inequalities, Partnership). SDG 17 identifies regional integration and regional entities in implementing the SDGs, opening up the prospect of a far larger role for IOs on a regional scale to influence global policy in this and other fields (Yeates 2017). Indeed, WHO is already highlighting a greater role for regional formations in managing health worker migration (WHO 2016; Chanda 2019). In many ways, though, this regional emphasis builds on extant trends in the Association of Southeast Asian Nations (ASEAN), the East African Community (EAC), the Southern African Development Community (SADC) and the EU whose institutional regimes already play a significant role in governing health worker recruitment and migration within their regional communities and their relations with 'third countries' (Yeates 2014, Yeates and Pillinger 2013, 2018). Also, the 2010 WHO Global Code has been implemented, in part, by being integrated into the European Commission Action Plan for the EU Health Workforce. Further measures or plans to integrate the principles into regional actions are reported from member states in the WHO Regional Office for the Eastern Mediterranean (EMRO) network (Arab League), the Andean network, the IberoAmerican General Secretariat (SEGIB) and the Council of Health Ministers of Central America (COMISCA) (WHO 2016). The SDGs' emphasis on partnership working is embedded in the idea of 'multistakeholderism', which structures diverse stakeholders (including INGOs, civil society organizations, employers, corporations) into policy formation for delivering the SDGs. In health, multistakeholder partnerships have so far been most obviously manifested in the increasing role of the private (for profit, corporate) sector in delivering universal health coverage and global health initiatives (Yeates and Pillinger 2019a, b).

Clearly there are different and competing currents running through the development of global policy in this field. In terms of the broad

\footnotetext{
${ }^{3}$ Echoes of this discursive shift are apparent in the inter-IO International Health Worker Mobility Platform.
} 
development of the field, this review of its long history across its post-war era, the following points regarding the 'universe' of IOs populating this field may be highlighted.

First, WHO may currently be the IO that is most associated with this global policy field (by virtue of the 2010 Global Code), but from a longer historical perspective it has played a far less formative role. The ILO, UNESCO and UNCTAD, were at the foreground of shaping the definition of the global policy issues at stake and elaborating on concrete global policy proposals in the 1960s, prior to WHO's joining this field. Furthermore, WHO's contributions to the field have been uneven: decades have passed without it making any contribution at all. Despite this, WHO undoubtedly has the second longest presence among IOs in the field and presently functions as a principal convener of international initiatives in this field. The changing constellations of IOs over the period are also evident in how UNESCO and UNCTAD are no longer the principal protagonists that they once were (indeed, they have withdrawn from the field), and how the World Bank has been gaining greater prominence within the last decade.

Second, if the IOs involved in propelling the major initiatives and agreements can be taken as a proxy for the most powerful (influential) actor in the global policy field, then the ILO is the most consistently powerful UN social policy agency over time (see point above). In practice, though, the ILO and WHO have worked in informal partnership. This is most obviously seen in the 1970s when WHO handed over the task of translating the policy conclusions of its initiative to the ILO, which negotiated the Nursing Personnel Recommendation within the space of just one year. The dynamics of this historic partnership may well change over the coming years as the World Bank and others become more prominent.

Third, the changing constellation of IOs is seen in the expanding universe of IOs more generally. Prior to the 2000s, international non-state actors were comprised principally of international workers' and employers' organizations working through the ILO to form international labor standards. At the turn of the twenty-first century, this universe of non-statist IOs had pluralized: a far greater number and range are now involved, organizing the ethical recruitment movement. This movement originated with non-state actors (health professionals etc.) which have worked with state actors (some source and destination country governments) and IOs through the HWMI to campaign for the Global Code and its implementation. This multi-actor alliance has succeeded in renewing attention to 
connections between health, development, labor migration and labor conditions.

Fourth, the most significant advances in the institutionalization of global policy (indicated by concrete multilateral agreements) have tended to follow major global initiatives in two fields: international development (UN Development Decades, NIEO, MDGs, SDGs) and international migration (ILO labor migration initiatives of the 1970s preceding the ILO Nursing Personnel Recommendation; UN initiatives in the late 1990s/mid 2000s to 'thicken' global migration governance; most recently the migration-related aspects of SDGs, Global Compact). We must not discount the formative influence of global initiatives launching and sustaining neoliberalism and structural adjustment through finance, development, trade and health. This points to the conclusion that the broader canvas of IOs and the institutional regimes in which they are embedded are essential to understanding the dynamics of the global policy field of health worker migration governance. It is as important to attend to the broad canvas of global governance and policy when considering the population of relevant IOs (and discourses) and the dynamics of the global policy field as it is to those IOs more explicitly operating within the policy domain. This conclusion speaks to the idea of 'exogenous organizational ecology' (Niemann et al., in this volume).

\section{Key Discourses Promulgated by IOs}

The organizational features of this global policy field discussed in Section "Key Discourses Promulgated by IOs" indicate that just as there is no overarching global institutional migration governance framework on health worker migration, so there is no single predominant IO coordinating the policy field. This global policy landscape points to dispersed mandates, authority, responsibility and power among the population of IOs. Most of the principal IOs engage with health worker migration as part of their broader remit, but they address health worker migration and recruitment in quite different ways.

Indeed, looking more closely at the concepts, approaches and discourses in this field, we see multiplicity. IOs' policy discourses are multifarious. Policy issues identified differ from one IO to another, each of which institute initiatives reflecting their organizational mandate and priorities. Table 4.2 identifies in summary form the policy approaches and their underpinning key concepts, characteristic discourse(s) and exemplar 
initiatives and/or publications for eight IOs discussed in Section "Mapping the Population of International Organizations", namely: ILO, IOM, OECD, UNESCO, UNCTAD, World Bank, WHO and WTO. The table covers a long historical period; where applicable, it indicates any shift in approach and discourse of the IOs included in it. The WTO is bracketed here because although it has self-consciously abstained from this global policy field on the grounds that it addresses mobility of labor, not migration, the applicability of GATS, although uncertain, cannot be excluded entirely (WHO/The World Intellectual Property Organization (WIPO)/ WTO 2012). In any case, international services trade agreements in global policymaking in this field (as in others) have been enduringly attractive to some global actors so it is important that the WTO be included even if it is presently a 'passive' actor.

Table 4.2 shows the breadth of policy concepts, approaches and discourses evident in this field. These more or less clearly distinguish the IOs (columns 2 and 3 ) from one another, even though underpinning ideas such as the right to migrate, universal health coverage, ethical/fair recruitment and development benefits of migration are shared by them. However, these ideas are taken up and blended in quite different ways by different IOs. Among the UN agencies, the ILO, WHO, UNESCO and UNCTAD all subscribe to UN normative principles on human rights and equality, but each bring different perspectives that are, in turn, reflected in their discourses. The ILO's approach is grounded in promoting the highest international labor standards possible and social protection systems consistent with them, and accordingly discusses health worker migration and recruitment in terms of working conditions in countries of origin and employment and as a matter of social (labor) injustice. WHO's approach is rooted in meeting essential health needs in line with realizing strengthened health systems and universal health coverage. Its discourse is rooted in health workforce planning and health professional workforces as part of the planning, policy and administration of health services more generally in order to meet population health needs and global health goals. UNESCO's approach has been to highlight the loss of national investment in education and human development that results from permanent emigration of highly skilled health workers especially to richer countries in the Global North. During the 1960s, it was the most vociferous of all the active IOs at the time in emphasizing the need for a robust global policy capable of addressing and stemming the 'brain drain'. 
Table 4.2 Policy approaches and discourses of IOs in regard to health worker migration/recruitment

\begin{tabular}{|c|c|c|c|}
\hline$I O$ & Approach & Discourse & Exemplar initiative(s) \\
\hline ILO & $\begin{array}{l}\text { Decent work, } \\
\text { social } \\
\text { protection, } \\
\text { migrant } \\
\text { workers' rights }\end{array}$ & $\begin{array}{l}\text { Brain drain, brain gain, brain } \\
\text { circulation. Fair recruitment and } \\
\text { employment; pre-eminence of } \\
\text { ILO normative standards on } \\
\text { labor migration and social } \\
\text { protection for migrants }\end{array}$ & $\begin{array}{l}1949 \text { Migration for } \\
\text { Employment } \\
\text { Convention } \\
1977 \text { Nursing } \\
\text { Personnel } \\
\text { Recommendation } \\
1982 \text { Maintenance of } \\
\text { Social Security Rights } \\
\text { Convention }\end{array}$ \\
\hline IOM & $\begin{array}{l}\text { Circular } \\
\text { migration, } \\
\text { diaspora } \\
\text { engagement }\end{array}$ & $\begin{array}{l}\text { Brain gain, brain circulation; } \\
\text { harnessing social remittances for } \\
\text { 'development', supporting } \\
\text { transfer of knowledge, skills and } \\
\text { technology, and diaspora } \\
\text { capacity-building to benefit } \\
\text { source countries. }\end{array}$ & $\begin{array}{l}\text { IOM }(2006) \\
\text { IOM }(2008) \\
\text { IOM-funded study by } \\
\text { Tjadens, Weilandt and } \\
\text { Eckert }(2012)\end{array}$ \\
\hline OECD & $\begin{array}{l}\text { Health labor } \\
\text { markets, circular } \\
\text { migration }\end{array}$ & $\begin{array}{l}\text { Mutual benefit, brain circulation } \\
\text { (health sector efficiency/costs), } \\
\text { sustainable financing. }\end{array}$ & $\begin{array}{l}\text { OECD }(2008,2010 \\
2015)\end{array}$ \\
\hline UNESCO & $\begin{array}{l}\text { Uneven } \\
\text { development }\end{array}$ & $\begin{array}{l}\text { Brain drain as a factor of } \\
\text { depletion of investment in human } \\
\text { development. Redistribution, } \\
\text { compensation. Return migration } \\
\text { and reincorporation. }\end{array}$ & $\begin{array}{l}\text { UNESCO (1968) } \\
\text { UNESCO (1987) }\end{array}$ \\
\hline UNCTAD & $\begin{array}{l}\text { Reverse transfer } \\
\text { of technology, } \\
\text { trade- } \\
\text { development } \\
\text { nexus }\end{array}$ & $\begin{array}{l}\text { Brain drain. Outflows of health } \\
\text { workforce as: denial of a } \\
\text { country's access to development } \\
\text { resources; one-sided transfer of } \\
\text { productive resources embodying } \\
\text { technology in human skills. } \\
\text { Financial restitution } \\
\text { (compensation). }\end{array}$ & $\begin{array}{l}\text { UNCTAD (1979) } \\
\text { UNCTAD (1983) }\end{array}$ \\
\hline WHO & $\begin{array}{l}\text { Essential health } \\
\text { needs }\end{array}$ & $\begin{array}{l}\text { Human resources for health; } \\
\text { health professionals; health } \\
\text { workforce planning and } \\
\text { sustainability; ethical recruitment; } \\
\text { universal health coverage. Brain } \\
\text { drain, brain gain, latterly, brain } \\
\text { circulation. }\end{array}$ & $\begin{array}{l}\text { WHO }(2006) \\
2010 \text { WHO Global } \\
\text { Code of Practice on } \\
\text { the Ethical } \\
\text { Recruitment of Health } \\
\text { Personnel; } \\
\text { WHO }(2016)\end{array}$ \\
\hline
\end{tabular}


Table 4.2 (continued)

\begin{tabular}{|c|c|c|c|}
\hline$I O$ & Approach & Discourse & Exemplar initiative (s) \\
\hline WB & $\begin{array}{l}\text { Migration- } \\
\text { development } \\
\text { nexus }\end{array}$ & $\begin{array}{l}\text { Brain gain, brain circulation. } \\
\text { Labor market, fiscal and } \\
\text { development impacts of } \\
\text { migration } \\
\text { Temporary migration, knowledge } \\
\text { transfers from migration. } \\
\text { Has invoked the potential value } \\
\text { of international services trade } \\
\text { agreements to manage health } \\
\text { worker migration. } \\
\text { Universal health coverage }\end{array}$ & $\begin{array}{l}\text { Ratha and Mohapatra } \\
(2011) \\
\text { World Bank (2009, } \\
2012) \\
\text { WHO/OECD/WB } \\
(2018)\end{array}$ \\
\hline (WTO) & $\begin{array}{l}\text { (Trade in } \\
\text { services) }\end{array}$ & $\begin{array}{l}\text { (Brain circulation. Mobility i.e. } \\
\text { temporary migration) }\end{array}$ & $\begin{array}{l}\text { WHO/WIPO/WTO } \\
(2012)\end{array}$ \\
\hline
\end{tabular}

Source: compiled using data from Yeates and Pillinger $(2013,2018,2019 a)$, with additional analysis by the authors for this chapter

Beyond these IOs, the policy issues are framed in quite different ways. UNCTAD's policy discourse stands out for framing international health worker migration as an issue of 'reverse' transfers of resources from developing to developed countries which, it has argued, is a reflection of source countries' unequal positioning within the international trade and development system. Its interventions were significant at the time (during the 1960s-1980s) because they differed substantially from - and challengedthe policy discourses of WHO, the ILO and UNESCO in locating the 'brain drain' in the context of uneven trade and development within the world system. UNCTAD was also significant for its pioneering (but ultimately doomed) global policy proposals to regulate and stem such resource flows through global financial restitution mechanisms. The trade/labor/ development nexus perspective has more recently been taken up by the World Bank, which frames the issue as a matter of harnessing international migration dynamics for national and international development, albeit only recently beginning to engage with health worker migration dynamics through the lens of services trade and, latterly, universal health coverage. Its keenest interest has been in diasporic aspects of socio-economic development, particularly migrant remittances as a source of development finance, and in harnessing international services trade frameworks on a regional scale as a means of mobilizing labor and financial resources for 
regional (and national) economic development. With the very recent exception of WHO (WHO 2016), it has been the only IO which has an appreciable world-regional dimension to its policy discourse, which it has pursued largely through wider regional development initiatives. Indeed, world-regional social policy in the Caribbean, Africa and East/South-East Asia bear the imprint of World Bank encouragement of international trade in services approaches to health worker migration and recruitment policy which emphasize the value of temporary and circular migration of health (and other) workers to meeting the economic needs of countries (Yeates 2014; Yeates and Pillinger 2013, 2018).

Policy approaches and discourses, such as ethical recruitment, universal health coverage and so on, crosscut with those of 'brain drain', 'brain gain' and 'brain circulation' that transcend any one IO. These latter three concepts can be broadly demarcated over time. Thus, global policy discourses have shifted from emphasizing the loss of investment of public resources in human and wider development capacity of countries ('brain drain'), to emphasizing the benefits to source countries of their highly skilled labor emigrating to richer countries ('brain gain'), to emphasizing the 'win-win' outcomes for source and recruiting countries alike as a result of temporary migration implied by more 'free-flowing', 'circular' migration patterns ('brain circulation'). Even so, each of the IOs (and many INGOs) participate in these debates on quite different terms. These differences relate in turn to debates about the migration-development nexus that have become prominent in the global migration governance and policy field over the last two decades. Such debates tend, however, to be conducted in rather abstract terms, rarely connecting to the actual labor and living conditions of migrants themselves. One concern is that the concept of 'brain circulation' (and of circular migration more generally) feeds into political movements challenging the right to migrants' permanent settlement overseas. Otherwise, the concept of 'brain circulation' is particularly associated with the GFMD, IOM and the World Bank diasporic approaches and circular migration discourses. There are signs it is being adopted by WHO as well. The ILO remains skeptical of circular migration because its precepts are very similar to temporary migration; encouraging such migration risks undermining permanent migration rights and labor rights and standards.

The delineations among the IO population identified here have a material basis, connected as they are to the organizations' institutional mandates and governance structures. For example, the ILO's focus on labor migration and labor standards founded on non-discrimination (including 
on the basis of national origin) and human rights reflects its institutional mandate to protect 'the interests of workers when employed in countries other than their own' (Preamble, ILO Constitution 1944). Its tripartite governance structure (governments, employers, workers) coupled with its institutional provisions for monitoring the implementation of its instruments have been important for propelling its mission to codify international standards and embed them institutionally at country level. WHO, on the other hand, has no institutional mandate on migration per se. Nevertheless, it has routinely encountered the phenomenon of health worker migration and recruitment since it earliest day by virtue of being tasked 'to promote improved standards of teaching and training in the health, medical and related professions' (Article 2) as part of its 'responsibility for the health of their peoples and the provision of adequate health and social measures' and overarching objective for 'all peoples [to attain] the highest possible level of health' (Article 1). This objective and responsibility is guided by the principle that ' $[\mathrm{u}]$ nequal development in different countries in the promotion of health and control of disease...is a common danger' (WHO 1946), and opens the way to WHO's concern with how (in)adequately staffed health services combine with emigration in some country contexts. Unlike the ILO though, WHO is governed by member states (health ministries) via the World Health Assembly. Only member governments have 'proposal rights', and there is no constitutional duty, mandate or mechanism for formally incorporating non-state actors in its policy-formation process. Nor is there any means of monitoring the implementation of its instruments, save for what can be negotiated with governments and written into specific agreements on a case-by-case basis (Yeates and Pillinger 2019a, 29-30, 2019b).

The contrasting mandates and governance mechanisms differentially structure the participation and proposal rights of different actors (state, business and labor in the ILO, states in WHO), and produce varied institutional and political dynamics of IO policy formation (Yeates and Pillinger 2019a, 29-30). The ILO's tripartite governance structure has proved more conducive in framing and propelling global policy than WHO's structure which limits participation rights to member state governments. Internal organizational features of IOs are also important in structuring other IOs' policy discourse (and by extension the pace and timing of policy and international agreements). For example, ideas and discourses revolving around 'reverse transfers of technology' at UNCTAD brought labor migration into capital mobility debates. This had the effect of 
highlighting how the international migration of highly skilled (health) personnel constitutes a one-sided transfer of productive resources embodying technology in human skills, as well as the economic development consequences of outflows of such resources from poorer to richer countries (Yeates and Pillinger 2019a). These creative opportunities to connect labor, trade and development in global policy during the 1970s in particular were enabled by UNCTAD's thirdworldist mandate to enhance the participation of developing countries into global trade and development policy. UNCTAD's policy-making structures, which involved grouping countries into distinct negotiating blocs (advanced economies, communist countries, developing countries), strengthened the voices of those highlighting the economic development impacts of (human) capital mobility. They also helped compensatory approaches to global policy on health worker migration and recruitment to be articulated in ways that, although controversial and despite not being instituted in practice, have remained an enduring idea within the field since the 1960s (Yeates and Pillinger 2019a).

The range of policy concepts and discourses in this global policy field is at least as diverse as that of the population of IOs and the networks and constituencies in which they are embedded-if not more so. The delineations set out in Table 4.2 are heuristic devices that help distinguish principal policy characteristics of the organizations concerned. These policy characteristics tend to be stable over time, even if the emphasis (e.g., through work programs) is refreshed periodically. There is strong continuity of the ILO policy in this field, which has remained rooted in international labor standards and an appreciation of the multiple, intersecting social and economic policy sectors involved. There has also been continuity of WHO policy, which has remained grounded in essential health needs, universal health coverage and strengthened health systems. Yet these characteristics are not immutable; they change over time. New ideas are folded into organizational work programs, which may become institutionalized in policy. For example, WHO took up the idea of ethical recruitment in the mid-2000s and featured it in the 2010 Global Code. A similar process may be occurred in relation to gender equality, with WHO recently recognizing the need for gendered health workforce strategies (WHO/ GHWN/Women in Global Health (WGH) 2018), and in relation to temporary and circular migration (see footnote 3 , above). The fundamental discursive characteristics remain stable but they evolve over time. Thus, what we see in current WHO discourse is continuity with older ideas of 
ethical recruitment, voluntary self-regulation and universal health coverage blending in its present-day focus on the benefits of temporary and circular migration. This is leading to a discursive shift in WHO (as with other IOs) away from 'brain drain' toward embracing 'brain circulation', with attendant consequences for global policy on migration more generally.

Nor are the policy characteristics of any one IO necessarily uniform at any one point in time. They may be articulated only in some parts of the world, as in the case of the World Bank's support for an international services trade policy approach in the Caribbean context but not, it seems, in other regional contexts. Is this simply a reflection of creative opportunities available in the region to advance this agenda, such as resources and strategic priorities of the WB regional office for Latin America, or of certain features of the region's history? IOs are large, complex, multi-faceted organizations spanning multiple country and regional contexts, each of which has its own histories, constellations of policy actors and 'stakeholders', and institutional landscapes. Moreover, multiple IOs are co-present in any different regional or country context, and so the constellations of global actors, drivers and politics of policy vary considerably at any one point in time. This raises an analytical (and methodological) question: What can be taken as IOs' definitive policy position at any moment in time? Where do we 'look' to 'read' IO policy discourses? A reading of, say, ILO policy, with its codified international labor standards, seems straightforward enough. But how and why is it that some regional offices of IOs seem to promote particular aspects of the organization's policy? In WHO's case, for example, its Europe and South-East Asia offices have been the most visibly active in implementing the WHO Global Code. Might we understand this apparent anomaly as qualifying the idea of a singular, overarching policy, as a reflection of context-dependent resources, or as differences in leadership - or a combination of these? Finally, we should note that additional multilateral frameworks (and IOs) governing international health worker migration/recruitment also come into play. For example, in Asia Pacific, ASEAN's approach allies most closely with that of the WTO (health migration and recruitment as a trade in services issue) (Yeates and Pillinger 2018). Regional-level IOs 'overlay' global-level ones, offering competing or complementary normative and policy frameworks conditioning the work of governments (and others). In Asia Pacific, the ILO, $\mathrm{WHO}$, the WB and so on sit alongside regional IOs, such as ASEAN, regional development banks and regional dialogic mechanisms for migration governance (Yeates and Pillinger 2018). 


\section{INTER-ACTOR RELATIONSHIPS OF COOPERATION, CoOrdination and Contestation}

A relational approach to global policy development (Yeates and Pillinger 2019a) emphasizes that IOs do not work in isolation from each other or the wider global and national institutional and political fields in which they are embedded. As discussed in Section "Key Discourses Promulgated by IOs", there is much crossover among IOs' policy discourses, even if distinct policy approaches and IOs can be identified. Indeed, global policy discourses are blended from multiple sources and, in turn, circulate among IOs and their constituencies. Considering these interactions, this section turns to consider further inter-IO relations of cooperation and contestation through the lens of the formal and informal partnerships they forge with one another. Indeed, partnerships are a key feature of how IOs relate to each other and other actors.

Inter-IO relations have been a feature of this global policy field when it was substantially initiated and progressed within the UN system during the 1960s. These relationships, between the ILO, UNESCO, UNCTAD and WHO, seem to be ones of coexistence within the wider UN system. As separate (and relatively young) UN agencies, they were developing their programs in accordance with their organizational mandates and priorities in the context of a rapidly developing realm of action being carved out by the UN as a whole on a range of issues of interest-from international human rights instruments to the first UN development decade program-to give tangible meaning to the UN overall mandate. A range of UN bodies besides the four major UN agencies were involved (e.g., United Nations General Assembly (UNGA), United Nations Economic and Social Council (ECOSOC), office of the United Nations SecretaryGeneral (UNSG), UN Advisory Committee on the Application of Science and Technology for Development, UN Conference on Science and Technology for Development, UN Institute for Training and Research, Commission for Social Development). Although these were essential in developing and approving UN agencies' policy initiatives within the wider UN system, by themselves they do not testify to specific partnership relations among the agencies beyond the generality of common membership of the UN.

Partnership relations became more apparent in the 1970s, in the guise of informal cooperation between the ILO and WHO. WHO's major international study of international physician and nurse migration was 
curtailed early, and, with the prospects of the policy conclusions being incorporated into a WHO policy program rapidly diminishing, there was an opportunity to pass the 'baton' to the ILO, whose own employment program, which included a labor migration and gender equality strand, was being elaborated at the time. The ILO negotiated and concluded the Nursing Personnel Recommendation in record time. A representative of WHO was present at part of the passage of the Recommendation (Yeates and Pillinger 2019a, 64-74). This is a good example of inter-IO cooperation, one that is all-the-more significant because the Recommendation was the first multilateral agreement setting international standards on international health worker migration and recruitment.

Later decades provide more instances of inter-IO partnership working. These instances have increased in frequency since the 2000s as global social policy and development agendas have come together, first around the MDGs (2000-2015) and later around the SDGs (2016-2030). Over the last two decades, engagement by multiple IOs in partnerships (or, at least, alliances) has been a defining discursive and institutional feature of this field. This has been important given the multi-sectoral nature of the phenomenon. Indeed, such partnerships were key to the Global Code (WHO 2010), the international campaign for which involved an alliance between WHO, IOM and the ILO working within the multi-stakeholder Health Worker Migration Initiative (HWMI) ${ }^{4}$ and the high-level Global Policy Advisory Council (Yeates and Pillinger 2019a, b). Another example is the global Commission on Health Employment and Economic Growth (HEEG 2016), whose recommendations to increase investment in highquality health jobs-rich economic growth strategies to underpin the SDGs (including health and health-related goals) were premised on cooperative and coordinated joint ILO-OECD-WHO work to address health worker shortages. This has been taken forward through the International Platform on Health Worker Mobility set up under the joint ILO-OECDWHO Working for Health program and proposals to set up an international fund, the Working for Health Multi-Partner Trust Fund (MPTF), to support countries in expanding and transforming their health workforce (Dublin Declaration 2017). Questions here are whether these

${ }^{4}$ HWMI was established as a partnership between the NGO Realizing Rights: The Ethical Global Initiative and the Global Health Workforce Alliance (GHWA) in 2006 in response to the heightened concerns about the need for global responses to health worker migration and recruitment and was a crucial actor during the negotiations (Yeates and Pillinger 2019a, b). 
initiatives are more than an umbrella for a division of specialist labor among the IOs, and whether they are leading not just to collaborative activities but to coordinated ones-and if so, how are concepts, discourses and structural authority and power being reconfigured?

Inter-IO partnership working has become integral to the present-day global policy field, bringing much-needed multiple perspectives on the complex, multi-sectoral issues at hand, but such cooperation is not without tensions. We are not suggesting that IOs are pursuing parallel agendas within this joint global program of work, but competing policy approaches and discourses seem to be resilient-in no way subordinated or diluted under the banner of unity; still relatively fluid and in no way fixed or unchanging. One illustration of this is the Global Skills Partnerships initiative,${ }^{5}$ which has gained some traction in recent years. Favored by the OECD (2018), for example, such partnerships are seen as a means to derive mutual benefit-a 'win-win' solution to reconciling the continuing need for highly skilled immigrant health workers with source countries' capacity to keep 'producing' health workers willing to emigrate. Global Skills Partnerships are also flagged in the Global Compact (UNGA 2018) (Art.33(e)) as a way to link migration and skills development for the mutual benefit of migrants, and source and destination countries.

These partnerships are mired in controversy though because there are concerns that they open paths to greater reliance on private financing for education and training and international trade in health services. There is also a great deal of uncertainty as to how they will fulfill their promise of simultaneously contribute to a net creation of health workers in the source country, mitigate the effects of health worker migration and prove an effective way of addressing health workforce availability and promoting health system sustainability. There are also unanswered questions about how they will ensure ethical recruitment and rights-based approaches to

${ }^{5}$ Global Skills Partnerships (GSPs) are essentially bilateral agreements that mobilize resources for the training of skilled health workers in source countries, equipping health workers with the relevant skills and visas to migrate to work for an agreed duration in the country of destination that funded their training. Such an agreement allows mutual gains by taking advantage of large international differences in both professional earnings and training costs (Clemens 2017, 1). Clemens' idea is that GSPs would be formed on the basis of bilateral agreements where destination country governments directly fund training and skills development programs prior to migration. He argues they avoid the loss of resources from source countries when a trained health worker migrates to work abroad on time-limited contracts, returning 'home' afterward. 
migration (i.e., uphold the principles of the WHO Global Code). There are specific concerns that they may further embed temporary and circular health worker migration schemes (and related quotas) rather than promote permanent migration and other rights-based approaches to migration established by the UN and the ILO (Yeates and Pillinger 2019a, 190-193). In terms of the present discussion about sources of tension and potential fracture in inter-IO relations, it is worth highlighting that the dominant discourse in relation to Global Skills Partnerships revolves around financial incentives, employability, skills transfer and mobility rather than around health systems strengthening, health systems sustainability, health equity, decent work and social protection. These discursive shifts signal a potential turn away from UN normative principles, insofar as the OECD and the WB are associated with the dominant discourse in relation to Global Skills Partnerships, and the ILO and WHO associated with the labor and health rights-based one. In these partnerships, alternative narratives among the IOs could signal fracture lines in the new politics of IO cooperation around the health workforce aspects of the global health goals (Yeates and Pillinger 2019a).

\section{Conclusion}

This chapter has examined constellations of global policy actors (principally IOs), as well as ideas and discourses in the global policy field of health worker migration. Among the oldest post-WWII global social policy fields, the organizational center of gravity of this field has lain within the UN system. From the outset, we see multiplicity in terms of the population of IOs and policy concepts, approaches and discourses. Nongovernmental IOs were limited to international workers' and employers' organizations. Ensuing decades have seen the continual participation of (especially) the ILO and WHO, the exit of UNESCO and UNCTAD from the field, and the entry of the OECD, IOM and the World Bank and, prospectively, the WTO. UNICEF has never had a presence in the field. Regional-level IOs have not been a central feature of this chapter, but there is evidence that they are an already-important part of the IO topography in this field and that they may increase in significance in the future.

The ILO stands head and shoulders above other IOs for being the single most continuously present and active IO in the field. Given the mandate and governance structure of the ILO, this also means that IOs of workers and employers are the most long-standing and active of all IOs in 
the policy field. Since the 2000s, however, the population of nongovernmental IOs has expanded significantly, to the point that such actors extend well beyond workers' and employers' organizations. Their participation has added further perspectives and complexity, not least because these IOs are drawn from development, migration and health (and healthrelated) NGOs. A notable feature of this non-governmental population of IOs is the Global Health Workers Alliance (now Global Health Workers Network) which is unique in the field. Inter-IO cooperation has long been evident in the field and has intensified in recent decades, notably since 2000 (corresponding with the MDGs), during which time those relationships have moved from informal partnerships to more formal ones.

Over this time, IOs' policy approaches have been stable, with competing (and sometimes complementary) emphases on labor standards, health services, diaspora engagement, economic development and trade. However, policy discourses have shifted considerably along many axes. Perhaps the most significant of these shifts revolves around the labor-migrationdevelopment nexus, as captured in the concepts of brain drain, brain gain and brain circulation. Ethical recruitment, mutual benefit and mobility (as distinct from migration) have become key policy concepts. The notion of depletion may be an emerging concept, paralleling ongoing preoccupations with, and anxieties about, 'shortages' and resource extractivism that international recruitment signifies. In some quarters, brain/care drain still has considerable purchase, even if it is seen as problematic by many.

The growth of inter-IO partnering in global policy development seems to correspond with accommodations of various kinds among IOs in the field. Contemporary forms of inter-IO relationships oriented toward collaboration and cooperation have attenuated-but not eliminated-some historic tensions. In this respect, this chapter has pointed to emergent fracture lines in relation to Global Skills Partnerships, where predominant essential health needs and social protection approaches are being challenged by discourses of mobility (notably temporary and circular migration), financial incentives, employability and skills transfers.

This discussion ends on two points of critical reflection. The first concerns organizational ecology (cf Niemann et al, this volume). We highlighted the significance of both endogenous and exogenous organizational ecology in materialist understandings of global social policy formation in relation to any one IO. Internal governance structures determine global policy approaches as much as specific initiatives, where the former tend to be enduring and structurally formative and the latter are battlegrounds over 
which competing policy approaches and discourses are fought out. We also highlighted the temporally and geographically contingent nature of this organizational ecology, which is fluid and varied rather than fixed and uniform. This points to the value of taking a broad view on what counts as an IO's exogenous organizational ecology rather than delimiting the view only to IOs directly and explicitly participating in the field. The second point of reflection relates to the levels metaphor used so often in global social policy and governance studies. The concept of scale, rather than level, may be a more pertinent one, because it brings us closer to a form of global social policy analysis cognizant of how IOs of many different kinds work across multiple spaces of transnational governance that, in turn, are dynamically interacting. An appreciation of organizational ecology and the interactions at once constituting and deriving from it should therefore encompass relations among populations of IOs across multiple scales. Constellations of actors, ideas and policies in the architecture of global social governance and policy will be context-specific, that is formed from concrete situations circumstances, times and places.

\section{REFERENCES}

Chanda, Rupa. 2019. Regional Harmonisation Processes of Health Professional Regulation: Status, Challenges, and Policy Directions. Paper to 2nd Review of Relevance and Effectiveness of the WHO Global Code of Practice on the International Recruitment of Health Personnel. 18-19 June. Geneva: WHO.

Clemens, Michael A. 2017. Global Skill Partnerships: a Proposal for Technical Training in a Mobile World. Washington DC: Centre for Global Development. Dublin Declaration. 2017. Dublin Declaration on Human Resources for Health: Building the Health Workforce of the Future. Fourth Global Forum on Human Resources for Health, Dublin, Ireland, 13-17 November.

High- Level Commission on Health Employment and Economic Growth (HEEG). 2016. Working for health and growth: investing in the health workforce. Report of the High- Level Commission on Health Employment and Economic Growth. Geneva: WHO.

International Labour Organization (ILO). 1944. Constitution of the ILO and Declaration concerning the aims and purposes of the International Labour Organisation (Declaration of Philadelphia). Geneva: ILO.

International Labour Organisation (ILO). 1949. Migration for Employment Convention (Revised). C097. Geneva: ILO.

International Labour Organisation (ILO) 1977. Nursing Personnel Recommendation. R157. Geneva: ILO. 
International Labour Organisation (ILO) 1982. Maintenance of Social Security Rights Convention. Cl52. Geneva: ILO.

International Organization for Migration (IOM). 2006. World Migration Report: the costs and benefits of international migration. Geneva: IOM.

International Organization for Migration (IOM). 2008. World Migration Report 2008: Managing Labour Mobility in the Evolving Global Economy. Geneva: IOM.

Organization for Economic Cooperation and Development (OECD). 2008. The Looming Crisis in the Health Workforce: How can OECD Countries respond? OECD Health Policy studies. Paris: OECD.

Organization for Economic Cooperation and Development (OECD). 2010. International Migration of Health Workers: Improving International Cooperation to Address the Global Health Workforce Crisis. Policy Brief. Paris: OECD.

Organization for Economic Cooperation and Development (OECD). 2015. International Migration Outlook. Paris: OECD.

Organization for Economic Cooperation and Development (OECD). 2018. "What would make Global Skills Partnerships work in practice?" Migration Policy Debates, No. 15, May 2018, Paris: OECD.

Ratha, Dilip, and Sanket Mohapatra. 2011. "Preliminary Estimates of Diaspora Savings". Migration and Development Brief No. 14, Migration and Remittances Team, Washington DC: World Bank.

Tjadens, Frits, Caren Weilandt, and Josef Eckert. 2012. Mobility of Health Professionals: Health Systems, Work Conditions, Patterns of Health Workers' Mobility and Implications for Policy Makers. Berlin: Springer-Verlag.

United Nations Conference on Trade and Development (UNCTAD). 1979. Development Aspects of the Reverse Transfer of Technology. A/C.2/34/L.130, 14 December 1979. New York: UNCTAD.

United Nations Conference on Trade and Development (UNCTAD). 1983. Consideration of Recommendations on Policies and Concrete Measures with a View to mitigating the Adverse Consequences for the Developing Countries of the Reverse Transfer of Technology, including the Proposal for the Establishment of an international Labour Compensatory Facility. TD/B/AC.35/2. 17 June. UNCTAD: Geneva.

United Nations Educational, Scientific and Cultural Organisation (UNESCO). 1968. The problem of emigration of scientists and technologists: General appraisal of the phenomenon. Preliminary Report prepared at the request of the Advisory Committee of the Economic and Social Council on the Application of Science and Technology to Development, SC/WS/57, 29 February 1968, Paris.

United Nations Educational, Scientific and Cultural Organisation (UNESCO). 1987. The Brain Drain Problem: its Causes, Consequences, Remedies and the Role of UNESCO in this Regard. 127 EX/SP/RAP.2, 27 August 1987. UNESCO: Paris. 
United Nations General Assembly (UNGA). 2018. Global Compact for Safe, Orderly and Regular Migration. New York: UNGA.

World Bank. 2009. The Nurse Labor and Education Markets in the English-speaking CARICOM: Issues and Options for Reform. Report No. 48988LAC. Washington, DC.: World Bank.

World Bank. 2012. Towards a Regional Strategy to Strengthen the Nurse Workforce of the English-speaking CARICOM: International Legal Instruments, Agreements and Obligations. Report No. 62282-LAC. Washington, DC: World Bank.

World Health Organization (WHO). 1946. Constitution of WHO, Official Records of the World Health Organisation, 2, 100. Geneva: WHO.

World Health Organization (WHO). 2006. The World Health Report 2006 Working together for Health. Geneva: World Health Organization.

World Health Organization (WHO). 2010. WHO Global Code of Practice on the International Recruitment of Health Personnel. Geneva: WHO.

World Health Organization (WHO). 2016. Global Strategy on Human Resources for Health: Workforce 2030. Geneva: World Health Organization.

World Health Organization (WHO)/Global Health Workforce Network (GHWN)/Women in Global Health (WGH) (2018) Working Paper on Gender \& Equity in the Health and Social Care Workforce. Consultative Draft Report. Geneva: WHO.

World Health Organization/World Intellectual Property Organization/World Trade Organization (WHO/WIPO/WTO). 2012. Promoting Access to Medical Technologies and Innovation: Intersections between Public Health, Intellectual Property and Trade. Geneva: WTO.

World Health Organisation/OECD/World Bank. 2018. Delivering quality health services: a global imperative for universal health coverage. Geneva.

Yeates, Nicola. 2010. "The globalisation of paid care labour migration: policy issues, approaches and responses." International Labour Review, 149 (4): 423-440.

Yeates, Nicola. 2014. "The Socialisation of Regionalism and the Regionalisation of Social Policy: contexts, imperatives and challenges." In Transformations in Global and Regional Social Policies, edited by Alexandra Kaasch and Paul Stubbs, 17-43. Basingstoke: Palgrave Macmillan.

Yeates, Nicola. 2017. "Beyond the Nation State: how can Regional Social Policy contribute to achieving the Sustainable Development Goals?" UNRISD Issue Brief 5, Geneva. http://www.unrisd.org/80256B3C005BCCF9/httpNetITF ramePDF? ReadForm\&parentunid=2BC03CBE0426A945C12581 EC0044 6D52 \&parentdoctype $=$ brief\&netitpath $=80256$ B3C005BCCF9 $/$ (httpAuxPag es ) /2 BC03CBE0426A945C12581 EC00446D52/\$file/IB5\%20-\%20 Regional-social-policy.pdf. Accessed February 20, 2020. 
Yeates, Nicola and, Jane Pillinger. 2013. Human Resources for Health Migration: global policy responses, initiatives, and emerging issues. Open University, Milton Keynes. http://oro.open.ac.uk/39072/. Accessed March 10, 2020.

Yeates, Nicola and, Jane Pillinger. 2018. "International Healthcare Worker Migration in Asia Pacific: International Policy Responses." Asia Pacific Viewpoint 59 (1). Wiley Online Library. (Open Access) https://onlinelibrary. wiley.com/doi/abs/10.1111/apv.12180. Accessed March 10, 2020.

Yeates, Nicola, and Jane Pillinger. 2019a. International Health Worker Migration and Recruitment: Global Governance, Politics and Policy. London: Routledge.

Yeates, Nicola, and Jane Pillinger. 2019b. Situating the WHO Global Code of Practice: looking back, looking forwards. Paper to 2nd Review of Relevance and Effectiveness of the WHO Global Code of Practice on the International Recruitment of Health Personnel. 18-19 June. Geneva: WHO.

Open Access This chapter is licensed under the terms of the Creative Commons Attribution 4.0 International License (http://creativecommons.org/licenses/ by $/ 4.0 /$ ), which permits use, sharing, adaptation, distribution and reproduction in any medium or format, as long as you give appropriate credit to the original author(s) and the source, provide a link to the Creative Commons licence and indicate if changes were made.

The images or other third party material in this chapter are included in the chapter's Creative Commons licence, unless indicated otherwise in a credit line to the material. If material is not included in the chapter's Creative Commons licence and your intended use is not permitted by statutory regulation or exceeds the permitted use, you will need to obtain permission directly from the copyright holder. 